\title{
Correction to: Alternatives to the EM algorithm for ML estimation of location, scatter matrix, and degree of freedom of the Student $t$ distribution
}

\author{
Marzieh Hasannasab ${ }^{1}$ (D) Johannes Hertrich ${ }^{1} \cdot$ Friederike Laus $^{2}$. \\ Gabriele Steidl $^{1}$
}

Published online: 15 July 2021

(C) The Author(s) 2021

\section{Correction to: Numerical Algorithms (2021) 87:77-118 https://doi.org/10.1007/s11075-020-00959-w}

The article Alternatives to the EM algorithm for ML estimation of location, scatter matrix, and degree of freedom of the Student $t$ distribution, written by Marzieh Hasannasab, Johannes Hertrich, Friederike Laus and Gabriele Steidl, was originally published electronically on the publisher's internet portal on 23 September 2020 without open access. With the author(s)' decision to opt for Open Choice the copyright of the article changed on 04 June 2021 to (C) The Author(s) 2021 and the article is forthwith distributed under a Creative Commons Attribution 4.0 International License, which permits use, sharing, adaptation, distribution and reproduction in any medium or format, as long as you give appropriate credit to the original author(s) and the source, provide a link to the Creative Commons licence, and indicate if changes were made. The images or other third party material in this article are included in the article's Creative Commons licence, unless indicated otherwise in a credit line to the material. If material is not included in the article's Creative Commons licence and your intended

The online version of the original article can be found at https://doi.org/10.1007/s11075-020-00959-w

Marzieh Hasannasab

hasannas@math.tu-berlin.de

Johannes Hertrich

j.hertrich@math.tu-berlin.de

Gabriele Steidl

steidl@math.tu-berlin.de

1 Institute of Mathematics, Technische Universität Berlin, Straße des 17. Juni 136, 10623 Berlin, Germany

2 Technische Universität Kaiserslautern, Paul-Ehrlich-Str. 31, 67663 Kaiserslautern, Germany 
use is not permitted by statutory regulation or exceeds the permitted use, you will need to obtain permission directly from the copyright holder. To view a copy of this licence, visit http://creativecommons.org/licenses/by/4.0.

Open Access This article is licensed under a Creative Commons Attribution 4.0 International License, which permits use, sharing, adaptation, distribution and reproduction in any medium or format, as long as you give appropriate credit to the original author(s) and the source, provide a link to the Creative Commons licence, and indicate if changes were made. The images or other third party material in this article are included in the article's Creative Commons licence, unless indicated otherwise in a credit line to the material. If material is not included in the article's Creative Commons licence and your intended use is not permitted by statutory regulation or exceeds the permitted use, you will need to obtain permission directly from the copyright holder. To view a copy of this licence, visit http://creativecommons.org/licenses/by/4.0/. 